\section{EMBRYARIDDLE Aeronautical University}

SCHOLARLY COMMONS
International Journal of Aviation, Aeronautics, and Aerospace

\title{
Book Review: Fundamentals of International Aviation
}

\author{
Alan Bender \\ Embry-Riddle Aeronautical University - Worldwide, bendef64@erau.edu
}

Follow this and additional works at: https://commons.erau.edu/ijaaa

Part of the Aeronautical Vehicles Commons, Atmospheric Sciences Commons, Aviation and Space Education Commons, Aviation Safety and Security Commons, Environmental Studies Commons, International Economics Commons, Maintenance Technology Commons, Management and Operations Commons, Navigation, Guidance, Control and Dynamics Commons, Other Aerospace Engineering Commons, Other Environmental Sciences Commons, Other Physical Sciences and Mathematics Commons, Public Policy Commons, Science and Technology Studies Commons, Tourism and Travel Commons, and the Transportation Commons

\section{Scholarly Commons Citation}

Bender, A. (2018). Book Review: Fundamentals of International Aviation. International Journal of Aviation, Aeronautics, and Aerospace, 5(3). https://doi.org/10.15394/ijaaa.2018.1260

This Book Review is brought to you for free and open access by the Journals at Scholarly Commons. It has been accepted for inclusion in International Journal of Aviation, Aeronautics, and Aerospace by an authorized administrator of Scholarly Commons. For more information, please contact commons@erau.edu. 


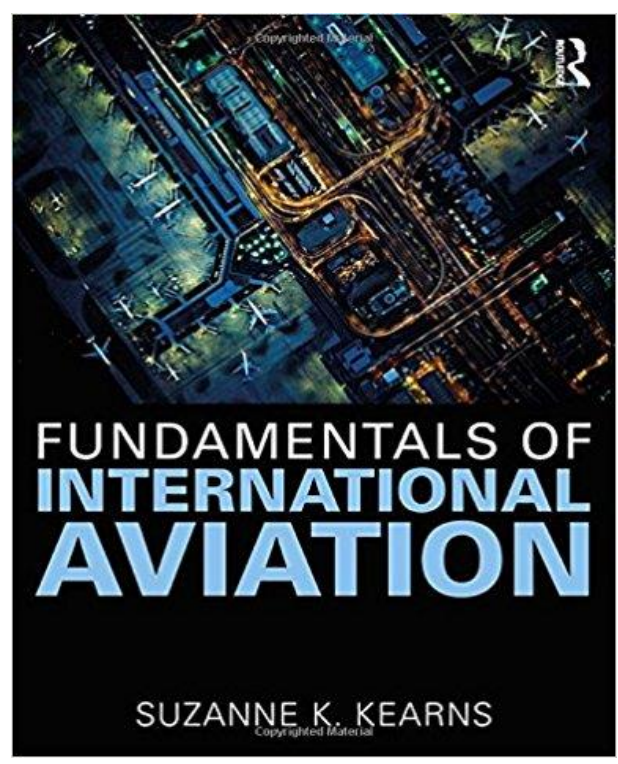

Book: Fundamentals of International Aviation

Author: Suzanne K. Kearns

Publisher: Routledge

Year: 2018

Book Price: $\$ 47.95$

eBook Price: $\$ 41.99$

Length: 372 pages

Read Time: Varies (average reader would take 11 hours)

Read Rating: $3.5-$ Good

Book Rating: 4.0 - Very Good

Dr. Suzanne Kearns, an Associate Professor in the aviation program at the University of Waterloo (Canada), turns the traditional introduction to aviation curriculum upside down with her groundbreaking new text. Kearns has a diverse background in myriad areas of aviation, including flying planes and helicopters to conducting human factors research to years of teaching introductory aviation classes to hundreds of college students.

Dr. Kearns has truly broken the mold with Fundamentals of International Aviation, and mostly for the better. Many introductory aviation texts pay little more than lip service to non-U.S., non-airline, and non-regulatory issues. The reality, at least in the $21^{\text {st }}$ century, is that aviation is not simply U.S. centric or airline centric. Kearns recognizes that educating the next generation of aviation professionals means getting away from most or even all of the old models of introductory aviation education.

From page 1, Kearns' text literally forces the reader to comprehend that aviation has shrunken the world so much that an understanding of international aviation rules and regulations is absolutely fundamental to understanding aviation itself. Aviation safety also plays a particularly prominent role in this introductory text. For example, while one expects to find case studies focusing on aviation accidents in selected chapters of any broad air transportation text, there are accident case studies embedded in literally every single chapter of Kearns' book, even chapters that seemingly have no direct connection to airplane crashes. This is a stroke of brilliance, as air travel has not become the safest mode of long-distance passenger transportation by chance. Safety is head-and-shoulders more important than any other aspect of the aviation business, it has to be, and Fundamentals of International Aviation acknowledges this reality by weaving aviation safety into practically every discussion, into practically every subject.

Topical coverage is also forward looking, with extensive, in-depth discussions of the latest breakthroughs in aviation security, remotely piloted aircraft, and other hot issues. One shortcoming, however, is the absence of very much coverage of modal competition and intermodality, critical issues today. Air transportation is by far the most intermodal of all 
motorized transport modes since practically no one lives or fully manufactures goods on or adjacent to airport grounds. Fact: Essentially $100 \%$ of airplane trips involve motorized ground transport at both origin and destination. And in Europe and China, high-speed rail is cutting into and even overtaking aviation's share of passenger traffic in many short- and even some mediumhaul markets. Even a limited discussion of aviation's role in the intermodal transportation system would have been appreciated.

On balance, however, Fundamentals of International Aviation is an important, compelling, and groundbreaking introduction to the ever-changing world of aviation and air transportation. Dr. Kearns has successfully articulated the excitement and myriad challenges of international aviation and, to be honest, of flying itself. This new textbook is a winner!

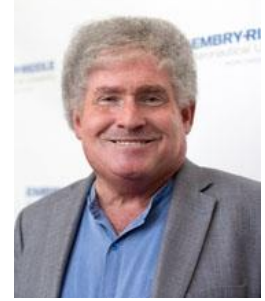

Alan R. Bender, Ph.D., is Professor of Aeronautics in the College of Arts and Sciences at Embry-Riddle Aeronautical University-Worldwide, and Smithsonian Research Associate at the National Air and Space Museum. He is a former Alfred Verville Fellow in Aeronautics at the Smithsonian Institution. Dr. Bender holds a Ph.D. in Geography and an M.S. in Transportation Engineering from the University of California, Berkeley. 